\title{
Kajian Tingkat Kepercayaan Publik Terhadap Dewan Perwakilan Daerah Provinsi Sulawesi Tenggara
}

\author{
La Husen Zuada ${ }^{1)}$ Muhammad Ahsan Samad ${ }^{1)}$ \\ ${ }^{1)}$ Fakultas IImu Sosial dan IImu Politik, \\ Universitas Tadulako, Palu, Indonesia \\ Email: husenzuadaui@gmail.com
}

\begin{abstract}
Abstrak
Tulisan ini mengkaji tentang tingkat kepercayaan publik terhadap DPRD Sulawesi Tenggara. Penelitian ini menggunakan pendekatan kualitatif dengan metode deskrpitif kuantiatif. Teknik pengumpulan data digunakan melalui metode angket, teknik dokumentasi, teknik wawancara, dan focus group discucssion. Hasil penelitian menujukkan bahwa tingkat kepercayaan publik terhadap DPRD Sulawesi Tenggara berada dalam kategori sedang dengan skor tingkat kepercayaan publik 3,23 skala likert dengan rentang kriteria sebesar $64,47 \%$. Penelitian ini merekomendasikan strategi meningkatkan kepercayaan publik, meliputi: a). Peningkatan akuntabilitas dan transparansi DPRD; b). Penguatan kelembagaan DPRD; c). Peningkatan pemahaman masyarakat tentang DPRD; d). Meningkatkan dukungan administrasi dan teknis terhadap pelaksanaan fungsi dan tugas DPRD; e). Peningakatan dukungan tenaga ahli/staf ahli; f). Optimalisasi peran Humas DPRD; g). Perwujudan teknologi informasi dan komunikasi yang terintegrasi; h). Pengelolaan website, penggunaan media sosial dan penyediaan TV dan Radio Parlemen serta majalah parlemen.
\end{abstract}

Kata kunci: Kepercayaan Publik, DPRD, Sulawesi Tenggara.

14 | Copyright @ 2019, JPAG, ISSN: xxxx-xxxx (Print), ISSN: xxxx-xxxx (Online) 


\title{
Study of the Level of Public Trust in the Regional Representatives Council Southeast Sulawesi Province
}

\author{
La Husen Zuada ${ }^{1)}$ Muhammad Ahsan Samad ${ }^{1)}$ \\ 1, Faculty of Social and Political Sciences, \\ Universitas Tadulako, Palu, Indonesia \\ Email: husenzuadaui@gmail.com
}

\begin{abstract}
This paper examines the level of public trust in the Southeast Sulawesi DPRD. This study uses a qualitative approach with quantiative positive methods. Data collection techniques were used through questionnaire methods, documentation techniques, interview techniques, and focus group discussions. The results of the study show that the level of public trust in the Southeast Sulawesi DPRD is in the moderate category with a public trust score of 3.23 scale likert with a criteria range of $64.47 \%$. This study recommends strategies to increase public trust, including: a). Increased accountability and transparency of the DPRD; b). DPRD institutional strengthening; c). Increased public understanding of the DPRD; d). Increase administrative and technical support for the implementation of the functions and duties of the DPRD; e). Increased support of experts / expert staff; f). Optimizing the role of DPRD Public Relations; G). Embodiment of integrated information and communication technology; $H$ ). Website management, use of social media and the provision of Parliamentary TV and Radio and parliamentary magazines.
\end{abstract}

Keywords: Public Trust, DPRD, Southeast Sulawesi. (Online) 


\section{PENDAHULUAN}

Posisi Dewan Perwakilan Rakyat Daerah (DPRD) dalam pemerintahan daerah memegang tiga peranan penting yaitu, legislasi, anggaran dan pengawasan. Eksistensi lembaga DPRD diharapkan dapat menyeimbangkan kekuatan terhadap pihak eksekutif daerah dengan cara menjalankan tiga fungsinya secara optimal. Survey Pol-Tracking tahun 2013 menunjukkan hanya 12,5 persen responden yang puas dengan kinerja parlemen. Tingkat kepercayaan publik terhadap legislatif dalam menjalankan fungsinya kian menghawatirkan, survey Polctraking pada tahun 2017 tentang evaluasi terhadap institusi demokrasi menempatkan legislatif sebagai lembaga yang meraih peringkat paling rendah tingkat kepercayaan publik yaitu peringkat 12 dari 13 institusi demokrasi yang disurvey.

Ketidakpercayaan tersebut lebih disebabkan oleh karena DPRD belum efektif dalam bekerja, belum representatif dalam kebijakan dan kinerja yang belum dapat dikatakan akuntabel. Temuan Polctraking (2017) menampakan bahwa kepuasaan publik terhadap legislatif dalam melaksanakan fungsi pengawasan hanya berkisar $36 \%$, membuat undang-undang 35 $\%$, penganggaran $33 \%$ dan penyalur aspirasi publik sebesar $29 \%$. Selebihnya, publik menjawab tidak puas dan tahu apa yang dikerjakan oleh legislatif. Lebih jauh, menilai rendahnya kinerja legislatif dalam menjalankan fungsinya tampak pada produk legislasi (UU dan Perda) yang dihasilkan banyak bermasalah dari sisi filosofi maupun manfaat. Pada sisi filosofi, produk legislasi yang disahkan kerap dibatalkan oleh Mahkamah Konstitusi dan Mahkamah Agung. Sementara dalam sisi manfaat, produk legislasi yang dibuat tidak mampu di implementasikan oleh para pelaksananya serta gagal mewujudkan ketertiban dalam masyarakat.

Di Sulawesi Tenggara persoalan yang menjadi keluhan terhadap kinerja DPRD yaitu berkaitan dengan kehadiran dan keaktifan anggota dalam rapat-rapat penting. Pada sidang paripurna yang dilaksanakan tahun $2017^{1}$, dari 45 anggota DPRD Sulawesi Tenggara yang hadir dan aktif menghadiri rapat berjumlah 26 anggota $(57,7 \%)$. Sebelumnya minimnya kehadiran anggota DPRD pernah terjadi ketika penyampaian laporan keterangan pertanggungjawaban gubernur Sultra pada 13 April 2017, dimana dari 45 anggota DPRD hanya 20 orang anggota $(44,44 \%)$ yang hadir, selebihnya tidak menghadiri rapat meski pihak sekertariat dewan telah menyampaikan udangan secara resmi. ${ }^{2}$ Rendahnya kehadiran anggota DPRD ini semakin minim pada hari-hari biasa (diluar sidang paripurna), dimana hanya $40 \%-60$ $\%$ saja yang rajin hadir di kantor DPRD, selebihnya mereka yang tidak hadir memiliki alasan bertemu konstituen. Alasan ini tentu tidak sesuai dengan jadwal dan agenda yang sudah ditentukan dalam tata tertib DPRD, dimana pertemuan dengan konstituen memiliki agenda tersendiri yaitu melalui reses.

Fenomena rendahnya kehadiran anggota DPRD Sulawesi Tenggara ini berkebalikan dengan tunjangan kinerja yang terus mengalami peningkatan. Kenaikan tunjangan ini tertuang dalam peraturan pemerintah Nomor 18 Tahun 2017. ${ }^{3}$ Peningkatan tunjangan dewan ini seyogyanya diikuti dengan peningkatan kinerja anggota legislatif serta keaktifan dalam rapat yang menjadi tugas pokok dan fungsi DPRD. Terkait minimnya kehadiran anggota DPRD ini diungkapkan oleh Yusuf yang tergabung dalam Gerakan Rakyat Peduli Demokrasi, dimana menurutnya kenaikan tunjangan anggota dewan

\footnotetext{
${ }^{1}$ Zona Sultra, "Setelah Tunjangan Dinaikkan, 13 Anggota DPRD Sultra malah absen paripurna", 11 September 2017.

${ }^{2}$ Zona Sultra, "LKPJ Gubernur Sultra, Puluhan Anggota DPRD Tidak Hadir", 14 April 2017.

3 Zona Sultra, "September, Pendapatan 45 Anggota DPRD Sultra Naik 15 Persen", 16 Agustus 2017.
} (Online) 
hendaknya sepadan dengan kinerja mereka. ${ }^{4}$ Citra negatif kelembagaan DPRD Sulawesi Tenggara tergambar pula dalam demonstrasi yang dilakukan oleh Forum Mahasiswa Anti Korupsi Indonesia (Formaki), dimana dalam demontrasinya Formaki mempersoalkan tidak transparannya proses lelang rehabilitasi rumah jabatan wakil ketua DPRD Sultra yang dilakukan oleh sekertariat DPRD. ${ }^{5}$ Fenomena ini memunculkan pertanyaan publik tentang seberapa transparannya kelembagaan DPRD dalam mengelola anggaran publik. Tidak transparannya DPRD juga tergambar dalam setiap agenda kegiatan yang dilakukan DPRD, dimana berbagai agenda DPRD tidak diketahui oleh publik secara luas. Akibatnya upaya kontrol publik terhadap agenda-agenda DPRD tidak berjalan optimal. ${ }^{6}$

Memahami peranan DPRD yang sangat strategis, menimbulkan harapan yang besar dari masyarakat agar para wakil rakyat yang terpilih untuk periode saat ini (2014-2019) dapat menyuarakan aspirasi dan harapan masyarakat, melaksanakan tanggung jawab dan kapasitasnya untuk memastikan bahwa proses pemerintahan dan pembangunan berjalan dengan baik, dimana salah satu indikatornya adalah perbaikan kinerja fungsi legislatif (DPRD). Dengan terlaksananya fungsi tersebut, maka apa yang menjadi harapan masyarakat (konstituen) dapat benar-benar terpenuhi, sehingga, pada akhirnya diharapkan kepercayaan masyarakat kepada DPRD akan meningkat. Penelitian ini bertujuan menemukan berbagai kendala dan menghasilkan rekomendasi untuk perbaikan kinerja DPRD guna meningkatkan tingkat kepercayaan publik terhadap DPRD.

Berdasarkan uraian di atas, maka artikel ini mencoba menjawab pertanyaan: a.Bagaimana kepercayaan publik terhadap DPRD Provinsi Sulawesi Tenggara?; b.

\footnotetext{
4 Zona Sultra, "Tunjangan Transportasi Naik, Akankah Anggota DPRD Rajin?", 4 September 2017.

5 Zona Sultra, "Kisruh Lelang Rehab Rujab, Wakil Ketua DPRD Sultra Menduga Sekwan Terlibat Pungli", 15 Juni 2017.

6 Zona Sultra, "Anggota DPRD Sultra Tidak Berada di Kantor, Mahasiswa Kecewa”, 24 Mei 2017.
}

17 | Copyright (c) 2019, JPAG, ISSN: xxxx-xxxx (Print), ISSN: xxxx-xxxx (Online)
Seberapa efektif kinerja DPRD (lembaga dan anggota) dalam menjalankan tugas dan fungsinya?; c. Bagaimana strategi mendorong kepercayaan publik terhadap DPRD Provinsi Sulawesi Tenggara?

Kepercayaan, Persepsi Publik dan Kinerja Legislatif

Dalam berbagai literatur, kepercayaan (trust) dikategorikan sebagai salah satu komponen modal sosial. Para ilmuwan yang membicarakan kepercayaan sebagai bagian dari modal sosial diantaranya, Coleman (1988), Putnam (1995), Fukuyama (1995). Ulasan Coleman tentang kepercayaan lebih banyak dikaitkan dengan persoalan ekonomi, seperti antara penjual dan pembeli. Lain pula Putnam yang membicarakan kepercayaan dengan menghubungkan berbagai pola aktivitas yang lebih luas, seperti: partisipasi politik, keanggotaan assosional, partisipasi keagaamaan, sukarelawan, amal, sosialisasi berbasis kerja, dan jaringan sosial informal.

Menurut Putnam, jaringan sosial memiliki nilai dan kontak sosial mempengaruhi produktivitas individu dan kelompok. Ibaratnya, jika seorang anggota DPRD memiliki jaringan sosial yang luas, maka produktivitasnya juga akan beragam. Sebaliknya, jika anggota DPRD memiliki jaringan sosial yang terbatas (hanya pada orang dekat, keluarga dan sahabat), maka produktivitasnyanya juga akan minim/terbatas. Untuk menumbuhkan produktivitas tersebut maka penting untuk memelihara hubungan individu (jaringan), norma dan keterpercayaan dalam hubungan-hubungan sosial. Menurut Putnam, kepercayaan (trust) adalah suatu bentuk keinginan untuk mengambil resiko dalam hubungan sosialnya yang didasari oleh perasaan yakin bahwa yang lain akan melakukan sesuatu seperti yang diharapkan dan akan senantiasa bertindak dalam suatu pola tindakan yang saling mendukung, paling tidak yang lain tidak akan bertindak merugikan diri dan kelompoknya (Putnam, 1995).

Lebih lanjut, Francis Fukuyama mendefenisikan kepercayaan sebagai unsur modal sosial yaitu kapabilitas yang muncul dari kepercayaan abadi di tengah-tengah masyarakat atau pada bagian tertentu dari 
masyarakat itu (Field, 2003). Menurut Fukuyama (2001), trust merupakan sikap saling mempercayai di masyarakat tersebut saling bersatu dengan yang lain dan memberikan kontribusi pada peningkatan modal sosial. Kepercayaan merupakan dasar dari tatanan sosial.

Kepercayaan adalah kemauan seseorang untuk bertumpu pada orang lain dimana kita memiliki keyakinan padanya. Kepercayaan merupakan kondisi mental yang didasarkan oleh situasi seseorang dan konteks sosialnya. Ketika seseorang mengambil suatu keputusan, ia akan lebih memilih keputusan berdasarkan pilihan dari orang - orang yang lebih dapat ia percaya dari pada yang kurang dipercayai (Moorman, 1993). Kepercayaan terjadi ketika seseorang yakin dengan reliabilitas dan integritas dari orang yang dipercaya (Morgan \& Hunt, 1994). McKnight, Kacmar, dan Choudry (dalam Bachmann \& Zaheer, 2006), menyatakan bahwa kepercayaan dibangun sebelum pihak-pihak tertentu saling mengenal satu sama lain melalui interaksi atau transaksi.

$$
\text { Miller/Listhaug (1990: 358) }
$$

menyebut kepercayaan mencerminkan tiga hal yaitu: 1). Evaluasi terhadap otoritas politik tentang siapa dan institusi apa yang tampil sesuai dengan harapan publik; 2). Ekspektasi warga tentang bagaimana pemerintah harus beroperasi meliputi: adil, jujur efisien dan tanggap terhadap kebutuhan masyarakat; 3). Kepercayaan pemerintah adalah penilaian ringkas bahwa sistem tersebut responsif dan ingin benar tanpa adanya pengawasan terus-menerus.

Kepercayaan memainkan peranan yang vital dalam memperoleh akses manfaat jaringan sosial, ekonomi dan politik. Dalam hal ekonomi misalnya, kepercayaan akan memudahkan transaksi lebih murah dalam proses jual beli barang. Dalam hal politik, ketidakpercayaan terhadap pemerintah (legislatif didalamnya) akan menjadi aspek yang kurang sehat bagi perjalanan demokrasi modern yang membutuhkan dukungan dan legitimasi dalam proses pengambilan keputusan.

Sementara itu, persepsi dapat diartikan sebagai pandangan atau pengamatan terhadap suatu objek yang telah diamati. Menurut Toha (1999: 138) menyebutkan bahwa "persepsi pada hakekatnya adalah proses kognitif yang dialami oleh setiap orang di dalam memahami informasi tentang lingkungannya, baik lewat penglihatan, pendengaran, penghayatan, perasaan dan penciuman. Kunci untuk memahami persepsi adalah merupakan penafsiran yang unik terhadap situasi dan bukannya pernyataan yang benar terhadap situasi". Menurut Kartono (1995: 50) memberikan defenisi sebagai berikut: a) Proses pengetahuan dan mengenali objek atau kejadian objektif dengan bantuan indera; b) Kesadaran dari proses - proses organism; c) Satu kelompok penginderaan dengan penambahan arti - arti yang berasal dari pengalaman masa lalu.

Dalam ilmu politik istilah persepsi berkaitan dengan perilaku atau sikap politik. Dalam pendekatan perilaku politik, terdapat interaksi antara manusia satu dengan lainnya yang akan selalu terkait dengan pengetahuan, sikap, dan nilai seseorang yang kemudian memunculkan orientasi sehingga timbul budaya politik. Orientasi politik itulah yang kemudian membentuk tatanan dimana interaksiinteraksi yang muncul tersebut akhirnya mempengaruhi budaya politik seseorang.

Almond dan Powell mencatat, bahwa aspek lain yang menentukan orientasi politik seseorang, adalah hal-hal yang berkaitan dengan "rasa percaya" (trust) dan "permusuhan" (hostility). Rasa percaya mendorong kelompok-kelompok dalam masyarakat untuk bekerjasama dengan kelompok lain. Sebaliknya rasa permusuhan akan mendorong seseorang atau suatu kelompok pada konflik politik (Alfian dan Nazaruddin Sjamsuddin, 1991: 22-23).

The Inter-Parliamentary Union (IPU) mengembangkan tool-kit untuk mengevaluasi fungsi/kinerja Parlemen. Toolk-kit yang dirilis oleh IPU terdiri lima indikator:? 1). Representative; 2). Transparent; 3). Accessible; 4). Accountable; 5). Effective. Proses penilaian

\footnotetext{
7 Evaluating Parliament - A self-assessment toolkit for parliaments", Inter-Parliamentary Union, 2008.
} (Online) 
kinerja DPRD ini melibatkan banyak aktor mulai dari pimpinan DPRD, perwakilan pemerintah, kelompok masyarakat sipil, akademisi, perwakilan partai politik dan lainnya. Indikator penentuan responden memperhatikan tingkat keahlian dan pengetahuannya serta mempertimbangkan keterwakilan gender. Penilaian ini akan dipandu dalam bentuk pertanyaan dikelompokkan menjadi lima bagian. Indikator ini didesain sedemikian rupa sehingga masing-masing tanggung jawab parlemen dapat dinilai.

\section{METODE PENELITIAN}

Penelitian ini menggunakan metode penelitian kualitatif deskriptif. Ulbert Silalahi (2012: 28) menyebut bahwa metode deskripsi terbagi dua yaitu deskriptif kualitatif dan deskripsi kuantitatif. Deskripsi kualitatif merupakan tahap permulaan dari perkembangan suatu disiplin. Sementara deskripsi kuantitatif menyajikan tahap yang lebih lanjut dari observasi, dimana peneliti meneruskan dengan mengukur besar atau distribusi sifat-sifat dari anggota kelompok. Dalam hal ini muncul peranan teknik-teknik statistik.

\section{a. Subjek Penelitian}

Subjek penelitian merupakan sumber data yang dimintai informasinya sesuai dengan masalah penelitian. Informan dalam penelitian ini meliputi: pimpinan DPRD Provinsi dan anggota DPRD Provinsi, Satuan Kerja Pemerintah Daerah (SKPD) di tingkat provinsi, tokoh masyarakat dan Lembaga Swadaya Masyarakat. Pemilihan informan dilakukan secara menyebar pada empat daerah pemilihan (Dapil) yaitu Dapil I, Dapil III, Dapil V dan VI.

\section{b. Teknik Pengumpulan Data}

1) Metode Angket.

2) Teknik Dokumentasi.

3) Teknik Wawancara.

4) Focus Group Discucssion.

\section{c. Metode Analisis Data}

Untuk menguji keabsahan data atau kebenaran hasil wawancara, pengamatan dan dokumentasi, dipergunakan teknik trianggulasi. Selanjutnya, teknik analisis data untuk masalah yang telah dirumuskan dalam penelitian ini, digunakan berdasarkan model analisis interaktif yang dikembangkan oleh Miles dan Huberman (1994), yaitu pengumpulan data, reduksi data, sajian data dan penarikan kesimpulan atau verifikasi.

Untuk menetapkan keabsahan data dalam penelitian ini dan penulis menggunakan kriteria dan pradigma sebagai berikut:

1.

Derajat

kepercayaan (credibility).

2. Keteralihan

(transferability).

$3 . \quad$ Kebergantungan

(dependability).

$4 . \quad$ Kepastian

(confirmability).

Sedangkan metode analisis yang digunakan adalah "analisis strategis" melalui pendekatan sistematis dan terukur. Pendekatan sistematis ditekankan pada data utama (primer) aspek kajian pendekatan terukur diarahkan pada penetapan variabel yang operasional sehingga data dapat diinterpretasi dengan tepat. Interpretasi data dilakukan secara kuantitatif dan kualitatif, untuk itu penelitian dimulai dengan menetapkan sebaran populasi/subyek penelitian berupa stakeholders dan dengan menggunakan teknik purposive, sedangkan untuk menentukan sampel penelitian menggunakan sampling quota berdasarkan identifikasi masalah.

\section{d. Interprestasi Data}

Interpretasi tentang tingkat kepercayaan publik terhadap DPRD diperoleh dengan metode rentang kriteria sehingga dihasilkan nilai persentase.

Penghitungan rentang kriteria menggunakan rumus sebagai berikut:

Rumus $=\mathrm{T} \times \mathrm{Pn}$

Dimana:

$\mathrm{T}=$ jumlah responden

Pn $=$ skor $1,2,3,4,5$

berikut:

Tahapan perhitungan sebagai

1. ST (Sangat tinggi) = Jumlah responden yang menjawab sangat tinggi dikalikan 5

2. $\mathrm{T}$ (Tinggi) $=$ Jumlah responden yang menjawab tinggi dikalikan 4. 


\section{JPAG (Journal of Public Administration and Government)}

Vol.1 (1), April 20119, 14-29

Lavailable online at http: http://jurnal.untad.ac.id/jurnal/index.php/jpag

3. $\mathrm{S}$ (Sedang) $=$ Jumlah responden yang menjawab sedang dikalikan 3

4. $\mathrm{R}$ (Rendah) $=$ Jumlah responden yang menjawab rendah dikalikan 2

5. SR (Sangat rendah) $=$ jumlah responden yang menjawab sangat rendah dikalilikan 1

6. Selanjutnya semua hasil 1-5 dijumlahkan menjadi TOTAL SKOR

Sebagai pembanding, apabila seluruh responden menyatakan sangat tinggi maka angka pembanding adalah skor tertinggi yang dinyatakan dengan rumus sebagai berikut: Responden

$\mathrm{Y}=$ Skor tertinggi Likert $\mathrm{x}$ Jumlah

Selanjutnya untuk mendapatkan hasil interpretasi dalam persentase dihitung dengan rumus sebagai berikut:

Rumus Indeks $\%=\frac{\frac{\text { TotalSkor }}{Y}}{Y} \times 100$

Untuk memudahkan interpretasi terhadap penilaian yaitu antara $20-100$ maka hasil penilaian tersebut diatas dikonversikan dengan nilai dasar 20. Untuk menentukan nilai persepsi dan kategori penilaian ditentukan berdasarkan interpretasi berikut:

Tabel. 1. Nilai Persepsi, Interval

Kepercayaan, Interval Konversi Kepercayaan, Mutu Kepercayaan dan Tingkat Kepercayaan

\begin{tabular}{|c|c|c|c|c|}
\hline $\begin{array}{c}\text { Nilai } \\
\text { Perse } \\
\text { psi }\end{array}$ & $\begin{array}{c}\text { Nilai } \\
\text { Inter } \\
\text { val }\end{array}$ & $\begin{array}{c}\text { Nilai } \\
\text { Interval } \\
\text { Konvers } \\
\text { i } \\
\text { Keprcay } \\
\text { aan } \\
\text { Publik }\end{array}$ & $\begin{array}{c}\text { Mutu } \\
\text { Keperca } \\
\text { yaan }\end{array}$ & $\begin{array}{c}\text { Tingkat } \\
\text { Keperca } \\
\text { yaan }\end{array}$ \\
\hline 1 & $\begin{array}{l}1,0- \\
1,8\end{array}$ & $20-36$ & E & $\begin{array}{l}\text { Sangat } \\
\text { rendah }\end{array}$ \\
\hline 2 & $\begin{array}{l}1,9- \\
2,6\end{array}$ & $37-52$ & D & Rendah \\
\hline 3 & $\begin{array}{c}2,7- \\
3,4\end{array}$ & 53-68 & $\mathrm{C}$ & Sedang \\
\hline 4 & $\begin{array}{c}3,5- \\
4.2\end{array}$ & $69-84$ & B & Tinggi \\
\hline 5 & 4.3-5 & $85-100$ & A & $\begin{array}{c}\text { Sangat } \\
\text { tinggi }\end{array}$ \\
\hline
\end{tabular}

\section{HASIL DAN PEMBAHASAN}

Kepercayaan Publik terhadap DPRD

Dalam rangka mengetahui tingkat kepercayaan publik terhadap DPRD maka digunakan sembilan variabel untuk mengukurnya, yaitu: a). Kepercayaan dan kejujuran; b). Tanggung jawab; c). Kompetensi; d). Kinerja; e). Peran; f). Kepedulian dan kedekatan; g). Komitemen; h). Integritas dan etika; i). Transparansi.

Secara keseluruhan hasil survei tentang tingkat kepercayaan publik terhadap DPRD Sulawesi Tenggara menunjukkan skor kepuasan 3,23 skala Likert. Apabila dihitung dengan rentang kriteria diperoleh hasil sebesar 64,47 persen (Tabel 2).

Tabel. 2. Tingkat Kepercayaan Publik Terhadap Dewan Perwakilan Rakyat Daerah Provinsi Sulawesi Tenggara Indikator Skor Tingkat Rentang Kepercayaan Kriteria (Skala $\quad(\%)$

Likert)

$1-5$

Kepercayaan dan $3,33 \quad 66,66$

kejujuran

Tanggung Jawab $\quad 3,06 \quad 61,25$

$\begin{array}{lll}\text { Kompetensi } & 3,35 & 67,16\end{array}$

$\begin{array}{lll}\text { Kinerja } & 3,45 & 69\end{array}$

Peran $\quad 3,11 \quad 62,25$

Kepedulian dan $3,01 \quad 60,33$

kedekatan

$\begin{array}{lll}\text { Komitmen } & 3,35 & 67\end{array}$

Integritas dan etika $\quad 3,61 \quad 72,25$

$\begin{array}{lll}\text { Transparansi } & 2,63 & 52,75\end{array}$

$\begin{array}{lll}\text { Tingkat } & 3,23 & 64,67\end{array}$

Kepercayaan

Publik terhadap

DPRD

Sumber: Hasil Pengolahan Data Penelitian, 2018

Tabel. 3. Nilai Persepsi, Interval

Kepercayaan, Interval Konversi Kepercayaan, Mutu Kepercayaan dan Tingkat Kepercayaan

\begin{tabular}{|c|c|c|c|c|}
\hline $\begin{array}{c}\text { Nilai } \\
\text { Perse } \\
\text { psi }\end{array}$ & $\begin{array}{c}\text { Nilai } \\
\text { Inter } \\
\text { val }\end{array}$ & $\begin{array}{c}\text { Nilai } \\
\text { Interval } \\
\text { Konvers } \\
\text { i } \\
\text { Keprcay } \\
\text { aan } \\
\text { Publik }\end{array}$ & $\begin{array}{c}\text { Mutu } \\
\text { Keperca } \\
\text { yaan }\end{array}$ & $\begin{array}{c}\text { Tingkat } \\
\text { Keperca } \\
\text { yaan }\end{array}$ \\
\hline 1 & $\begin{array}{c}1,0- \\
1,8\end{array}$ & $20-36$ & $\mathrm{E}$ & $\begin{array}{l}\text { Sangat } \\
\text { rendah }\end{array}$ \\
\hline 2 & $\begin{array}{l}1,9- \\
2,6\end{array}$ & $37-52$ & D & Rendah \\
\hline 3 & $\begin{array}{l}2,7- \\
3,4\end{array}$ & $53-68$ & C & Sedang \\
\hline 4 & $\begin{array}{c}3,5- \\
4.2\end{array}$ & $69-84$ & B & Tinggi \\
\hline 5 & $4.3-5$ & $85-100$ & A & $\begin{array}{c}\text { Sangat } \\
\text { tinggi }\end{array}$ \\
\hline
\end{tabular}
(Online) 
Berdasarakan hasil analisis di atas memberikan gambaran bahwa tingkat kepercayaan publik terhadap DPRD masih dalam kategori sedang. Untuk itu diperlukan berbagai terobosan dan kebijakan guna meningkatkan kepercayaan publik terhadap DPRD Provinsi Sulawesi Tenggara.

Melalui forum group discussion (FGD) Bapak Yusrianto (sekertaris Dinas Komunikasi dan Informasi Provinsi Sulawesi Tenggara) menyebutkan bahwa kepercayaan terhadap DPRD akan tumbuh jika paradigma berpikir publik tentang DPRD berubah. "ketidakpercayaan terhadap DPRD selama ini berkaitan dengan cara pandang atau paradigma berpikir kita. Kalau paradigma berpikir kita tentang legislatif datang, daftar, duduk, diam. Maka sampai sejauhmanapun legislatif bekerja, sebaik apapun dia bekerja, tidak akan pernah bagus. Oleh karena itu paradigma berpikir kita harus kita rubah dan DPRD juga berubah. Untuk merubah itu maka perlunya peran Sekwan untuk mengubah ini, ada publikasi. Jadi seharusnya DPRD ini bagaimana peran staff itu difungsikan, bagaimana mempublikasikan, mensosialisasikan apaapa yang dilakukan oleh DPRD, baik itu kegiatannya, visi-misinya, baik itu programnya. Supaya masyarakat memahami ternyata legislatif itu seperti ini”.

Hasil wawancara dengan La Nika, mantan anggota DPRD Provinsi Sulawesi Tenggara menyebut bahwa kepercayaan terhadap DPRD akan tumbuh jika DPRD dalam menjalankan tugasnya sesuai dengan undang-undang dan tanggung jawabnya. "Menurut saya kepercayaan terhadap DPRD akan muncul jika tugas mereka dilaksanakan sesuai undang-undang, sejalan apa yang diharapkan oleh masyarakat, itulah pelaksanaan tanggung jawab sebagaimana amanah dan aspirasi rakyat, tidak melakukan hanya dengan golongannya saja”.

Selanjutnya, berkaitan dengan tanggung jawab DPRD hasil wawancara dengan Syamsurizal, pengurus PMII Kabupaten Konawe menyebutkan bahwa:
"Ketika berbicara sifat tanggungjawab, saya memandang bahwa mereka yang terpilih dan telah diberikan amanah pastinya memiliki tanggungjawab yang besar dalam melaksanakan tugas dan fungsinya sebagai perwakilan dari konawe, namun realitasnya saat ini terkadang amanah tersebut berbenturan dengan kepentingan kepentingan lain. Maksud saya seringkali kepentingan umum dikesampingkan". Selanjutnya, hasil wawancara dengan Bapak Sahibo, S.E, selaku Kepala Kesbangpol Kolaka Timur menyebut bahwa kepercayaan publik terhadap DPRD berkorelasi dengan kualitas dan kompetensi DPRD dalam melakukan pengawasan, legislasi dan penganggaran. Menurut Sahibo, kualitas anggota DPRD masih minim. "Masih ada anggota DPRD yang berpendidikan SMA. Seharusnya pendidikan mereka minimal S1. Anggota DPRD sekarang banyak yang karbitan. Dulu anggota DPRD berasal dari birokrat yang punya banyak pengetahuan dan pengalaman birokrasi dan pembangunan. Dahulu era orde baru, anggota DPRD sangat terhormat dan disegani oleh masyarakat karena mempunyai pendidikan, pengalaman, dan kompetensi yang mumpuni, namun sekarang tidak lagi. Secara umum mereka sudah punya sifat tanggung jawab pada saat mereka bertugas, namun biasa saja. Begitupun dalam hal kompetensi anggota DPRD dalam melaksanakan tugas dan fungsinya masih biasa saja. Kurang menguasai tugas dan fungsinya. Kompetensi mesti didukung dengan SDM yang berkualitas, karena kapasitasnya sebagai penyambung aspirasi rakyat. Dalam hal pembuatan Perda anggota DPRD dalam merumuskan perda juga masih diwarnai oleh tindakan copy paste. Selain itu seringkali juga anggota DPRD studi banding ke daerah lain, lalu menerapkannya ke daerah tanpa mempertimbangkan cocok/sesuai tidaknya dengan keadaan daerah.". Lebih lanjut bapak Sahibo, S.E menyebutkan bahwa dalam proses penganggaran DPRD dengan eksekutif kerap tidak mencapai titik temu karena musyawarah perencanaan pembangunan (MUSREMBA-NG) yang digagas oleh eksekutif bersifat bottom up 
sementara keinginan DPRD bersifat top down. Usulan DPRD yang bersifat top down ini mengindikasikan DPRD dalam melakukan proses penganggaran tidak aspiratif (dari bawah). Hal ini menjadikan DPRD kehilangan makna sebagai representasi rakyat, dimana seharusnya dalam bekerja (penganggaran) DPRD dalam memberikan usulan melalui proses berjenjang dari bawah (bottom up) dan menampung aspirasi masyarakat sebagai dasar pengambilan keputusan. Dalam pengawasan pembangunan fungsi DPRD juga tidak efektif dikarenakan adanya oknum anggota DPRD yang mengerjakan proyek-proyek pembangunan. "Perencanaan pembangunan bukan berdasar pada hasil reses. Studi banding anggota DPRD hanya copy paste. Pada waktu musrembang anggota DPRD sering tidak hadir, sehingga penyerapan aspirasi yang diusulkan oleh masyarakat tidak berjalan dengan baik. Pokja di DPRD adalah sebagai inspektorat pelaksana pembangunan. Pengawasan dalam pembangunan kurang berjalan efektif disebabkan proyek-proyek pemba-ngunan yang dilaksanakan adalah terkait dengan oknum anggota DPRD, sehingga kualitas pekerjaan proyek kurang terawasi dengan baik. Yang penting proyek sudah jalan sebagai bukti fisik pekerjaan sudah dianggap selesai (aspek pengawasan kurang berjalan)".

Sementara itu hasil wawancara dengan sekertaris camat Pondidaha Kabupaten Konawe tentang kinerja DPRD dalam membuat Perda diceritakan sebagai berikut: "Kalau PERDA, ini yang tidak pernah kita dengar informasinya seperti ditelan bumi kalau yang beginian, apalagi di dapil ini tidak pernah kita dengar apakah mereka anggota DPRD dari Dapil sini membuat perda untuk kepentingan dan aspirasi masyarakat Konawe".

Senada dengan itu, Syamsurizal menyebut bahwa kinerja DPRD Provinsi dalam membuat Perda belum diketahui oleh masyarakat. "kita di daerah sini tidak pernah mendengar apa saja kebijakan yang sudah dibuat oleh DPRD provinsi mengenai daerah kami. Entah ini karna kurang informasi yang tidak dipublis atau bagaimana".
Sementara berkaitan dengan kinerja

DPRD dalam penganggaran, sekertaris camat Podidaha menceritakan sebagai berikut: "masalah penyusunan anggaran yang berorientasi kepada rakyat, jujur saja, kita disini di Konawe tidak pernah memahami pekerjaan - pekerjaan anggota DPRD dapil sini, karna selama ini yang sangat menyentuh langsung dengan anggaran kegiatan lebih banyak yang saya ketahui itu di anggota DPRD kab konawe. Kalau infrastruktur apalagi menyangkut jalan, banyak insiatif dari anggota DPRD kab konawe seperti jalan di Latoma itu merupakan inisiatif dari anggota DPRD kab Konawe".

Sementara itu dalam melakukan pengawasan, hasil wawancara dengan Syamsurizal, pengurus PMII Konawe melihat adanya sinergitas DPRD dan pemerintah dalam melakukan fungsi pengawasan. "Fungsi DPRD kan menjadi lembaga yang mengawas kerja - kerja pemeri-ntahan tentunya mereka punya kapasitas dalam pengawasan pembangunan. Selama DPRD dan pemerintah bersinergis tentu kebijakan pembangunan akan berjalan sesuai dengan tujuan provinsi. Kalau dilihat selama ini tidak ada ribut - ribut antara DPRD prov dan pemerintah prov. Artinya ini sinergis".

Kepercayaan terhadap DPRD akan terbangun jika antara rakyat, DPRD serta anggotanya memiliki kedekatan. Terkait dengan kedekatan DPRD dan rakyat Yusrianto memandang adanya keterputusan hubungan antara anggota DPRD dan masyarakat setelah terpilih. "anggota DPRD ini kan sudah ada daerah pemilihannya masing-masing, seharusnya ini tidak terputus, seperti misalnya ada anggaran untuk daerah pemilihan. Untuk peruntukannya ini seharusnya didiskusikan dengan masyarakat didaerah pemilihannya. Jangan ketika dia mau pemilihan baru mau turun lagi. Jadi seharusnya setelah dia dilantik itu dia jalankan terus menerus, ada disukusi dengan tokoh didaerah pemilihan, sehingga pada saat proses penganggaran nanti bisa dilaksanakan karena pendekatannya saling nyambung menyambung". 
Senada dengan itu hasil wawancara dengan Merlin Guluh (aktivis Koalisi Perempuan Indonesia Sulawesi Tenggara) menyebutkan bahwa: "Kedekatan antara anggota DPRD dengan masyarakat hanya berlangsung menjelang pemilihan. Setelah itu mereka menghilang entah kemana. Menjelang pemilu wajah-wajah mereka sangat familiar dan bertebaran disetiap sudut kota, namun setelah terpilih mereka menghilang".

Sementara itu hasil wawancara dengan Khabirun selaku Sekertaris Pimpinan Wilayah Gerakan Pemuda Ansor Sulawesi Tenggara menceritakan bahwa: "Saya secara pribadi memiliki kedekatan dengan beberapa anggota DPRD. Dulu kedekatan itu terbangun karena saya juga ikut memperjuangkan mereka untuk bisa terpilih. Sekarang kedekatan kami dengan anggota DPRD lebih dipengaruhi oleh ikatan organisasi. Misalnya jika ada calon anggota DPRD atau anggota DPRD terpilih yang berasal dari Ansor, maka kami melalui organisasi mendorong dan memperjuangkan mereka. Di Ansor kedekatan itu dilatarbelakangi oleh kesamaan organisasi, bukan beradasarkan partai, suku atau etnis. Siapapun, dimanapun dan darimanapun dia jika dia Ansor maka wajib kita dukung".

Senada dengan itu hasil wawancara dengan Ketua Pemuda Muhammadiyah Kabupaten Muna, Kubais menceritakan, sebagai berikut: "Semasa mahasiswa saya adalah aktivis maka pasti saya memiliki keakraban dengan anggota DPRD dan institusinya. Sejak saya mulai bekerja kedekatan itu masih tetap terbangun. Namun sekarang kedekatan itu agak berbeda karena saya juga menjadi ketua Pemuda Muhamadiyah. Di organisasi Muhammadiyah kedekatan dengan DPRD dilandasi oleh spirit ke-Muhammadiya-an".

Sementara itu hasil wawancara dengan akademisi selaku Ketua STIP Muna, Laode Hidayat Bolu mengungkapkan bahwa:

"Saya mengenal beberapa anggota DPRD khususnya di daerah pemilihan Kabupaten Muna, Muna Barat dan Buton Utara. Saya mengenal mereka selain mereka tokoh, juga sering menjadi pembicara di kampus.
Berkaitan dengan kedekatan dengan masyarakat itu saya tidak tahu persis. Namun sejauh ini saya amati mereka membangun kedekatan hanya pada saat menjelang pemilihan dan reses".

Menurut La Nika kepercayaan terhadap DPRD semakin menurun karena para anggota DPRD setelah terpilih melupakan visi misinya. "kadang-kadang anggota dewan itu melupakan visi misi sebagai perwakilan rakyat. Ini terjadi karena yang lolos bukan kader atau anggota partai. Seharusnya anggota DPRD berlatar belakang kader partai. Kalau dia kader partai pasti tugasnya dilakukan dengan baik. Masalahnya banyak partai yang mengirim anggotanya bukan kader. Sekarang ada beberapa partai yang mencalonkan itu tak melakukan rekruitmen kader dan diambil orang-orang bukan kader, sehingga dia lupa fungsinya dia ini mewakili rakyat. Kalau partainya melakukan kaderisasi maka dia mampu menggali masalah-masalah dari masyarakat, sehingga akan meningkatkan kepercayaan publik terhadap anggota legislatif tersebut, pada ujungnya dapat meningkatkan kepercayaan terhadap DPRD”.

Kepercayaan (trust) merupakan pondasi dari suatu hubungan. Suatu hubungan antara dua pihak atau lebih akan terjadi apabila masing-masing saling mempercayai. Kepercayaan ini tidak begitu saja dapat diakui oleh pihak lain, melainkan harus dibangun mulai dari awal dan dapat dibuktikan. Membangun kepercayaan tidak hanya memerlukan satu kali proses, namun memerlukan proses yang terus menerus.

Fungsi Dewan Perwakilan Rakyat Daerah (legislatif) sangat dibutuhkan dalam menjalankan pemerintahan atau organisasi. Peran itu berfungsi dengan baik, jika didukung kepercayaan rakyat. Kepercayaan merupakan salah satu aspek yang harus ada karena rakyat sebagai pemilik kedaulatan mempunyai hak istimewa dalam kehidupan politik demokrasi. Misalnya, Lembaga legislatif ada karena adanya rakyat. Rakyat memiliki harapan terwujudnya tatanan masyarakat yang adil, makmur, dan sejahtera di pundak politisi yang terpilih menjadi anggota legislatif. 
Kinerja Dewan Perwakilan Rakyat Daerah akan meningkat jika mengerjakan segala sesuatu untuk kepentingan rakyat dan banyak menjaring aspirasi rakyat. DPRD sebagai representasi rakyat harus mau membuka hati, membuka mata dan telinga, lalu melakukan tindakan dengan tangan dan kaki yang terbaik untuk rakyat. Adanya kepercayaan penting agar rakyat ikut aktif dalam proses jalannya pemerintahan.DPRD sebagai cabang kekuasaan pemerintahan membutuhkan kepercayaan publik dalam menjalankan fungsinya.

Sebagai lembaga politik, DPRD dalam menjalankan fungsi dan peranannya tidak berdiri sendiri, namun memiliki keterkaitan dengan kekuatan politik lain di dalam maupun di luar parlemen. Pertarungan kepentingan antar kekuatan politik merupakan fenomena yang tak terhindarkan dalam pengambilan keputusan di DPRD, terlebih lagi keputusan tersebut bersifat strategis. Untuk memenangkan pertarungan tersebut, maka keberadaan jaringan menjadi penting bagi anggota DPRD maupun lembaga DPRD itu sendiri. Tanpa jaringan yang kuat, maka DPRD akan mengalami kesulitan dalam meyakinkan publik tentang alasan memilih sebuah kebijakan.

Jaringan sosial merupakan aspek yang penting bagi DPRD karena adanya keterkaitan antara individu dalam kelompok. Eksistensi DPRD akan kuat tergantung pada kapasitas yang ada dalam kelompok masyarakat untuk membangun sejumlah asosiasi berikut membangun jaringannya. Dengan adanya jaringan sosial yang terjadi antara masyarakat dengan DPRD akan meningkatkan kerjasama yang terjalin.

Adanya kepercayaan terhadap DPRD akan membuat partisipasi publik dalam pelaksanaan fungsi parlemen meningkat. Hal tersebut dikarenakan kepercayaan merupakan landasan terbentuknya kerjasama dalam tim (kelompok). Solidaritas yang terjadi karena adanya kerjasama dan keadilan antara DPRD dan masyarakat akan menimbulkan hubungan timbal-balik (resiprositas). Dengan demikian publik akan lebih yakin untuk berpartisipasi karena mereka tidak merasa dirugikan, bahkan mereka mendapat hal positif, yaitu tercapainya tujuan individu maupun kelompok yang disepakati bersama.

\section{Kinerja DPRD}

\section{a. Pelaksanaan Fungsi Legislasi}

Dalam menjalankan fungsi legislasi DPRD Provinsi Sulawesi Tenggara periode 2014-2019 telah menghasilkan 78 Perda yang lahir dari inisiatif DPRD maupun eksekutif. 15 dari 78 Perda merupakan usulan dari DPRD Periode 2009-2013, namun dalam proses penomoran di Kementrian Dalam Negeri dilakukan pada saat masa kerja DPRD Provinsi Sulawesi Tenggara periode 2014-2019. Selanjutnya pada tahun 2018, berdasarkan Keputusan Dewan Perwakilan Rakyat Daerah Provinsi Sulawesi TenggaraNomor : 11 Tahun 2017 Tanggal 13 November 2017 DPRD Provinsi Sulawesi Tenggara sedang melakukan pembahasan pembuatan 23 Perda. Sebanyak 15 dari 23 Perda tersebut merupakan usulan eksekutif, sementara usulan legislatif berjumlah 8 usulan.Pada tahun 2018 pula DPRD Provinsi telah menyiapkan 5 rancangan Perda yang akan dibahas dalam sidang DPRD.

Tabel. 4. Rekapitulasi Perda Tahun 2013 - 2017

\begin{tabular}{|llll|}
\hline \multicolumn{2}{|c|}{ Peraturan Daerah } & \multicolumn{1}{c|}{ Jumlah } & $\%$ \\
\hline $\begin{array}{l}\text { Usulan } \\
\text { Daerah }\end{array}$ & Pemerintah & 48 Perda & 75,00 \\
\hline $\begin{array}{l}\text { Inisitatif } \\
\text { Provinsi }\end{array}$ & DPRD & 16 Perda & 25,00 \\
\hline Total & & & \\
\hline
\end{tabular}

Sumber: Sekwan DPRD Prov.

Sulawesi Tenggara, 2018

Dengan jumlah 64 Perda yang dihasilkan oleh DPRD Provinsi Sulawesi Tenggara selama kurun 4 tahun menujukkan lembaga ini cukup produktif dalam menghasilkan Perda. Akan tetapi dari produktivitas tersebut tampak adanya kelemahan dari DPRD dalam menginisasi lahirnya Perda, dimana hanya $25 \%$ Perda yang terbentuk dari usulan legislatif, sementara sisanya berasal dari usulan eksekutif. Oleh karena itu kedepan dalam rangka meningkatkan optimalisasi fungsi legislatif maka seyogyanya usulan Perda yang dilahirkan lebih dominan berasal dari usulan legislatif. Dengan demikian, maka 
dapat dikategorikan DPRD berfungsi optimal dalam melakukan fungsi legislasinya.

\section{b. Pelaksanaan Fungsi Pengawasan}

Pelaksanaan fungsi pengawasan dilakukan melalui berbagai kegiatan rapatrapat di DPRD bersama mitra kerja dan atau masyarakat melalui kegiatan Rapat Kerja (Raker), Rapat Dengar Pendapat (RDP), hearing. Selanjutnya untuk mengetahui fakta-fakta, permasalahan, atau tindaklanjut dari bidang masalah yang terkait dengan pelaksanaan Perda dan kebijakan Pemerintah, DPRD melakukan kunjungan kerja (Kunker) ke daerah yang ditentukan dan atau daerah pemilihan yang dilakukan pada masa reses.

Di samping kegiatan tersebut, pelaksanaan fungsi pengawasan DPRD juga dapat dilakukan dengan pelaksanaan hakhak DPRD, pembentukan Tim, Panitia Khusus (Pansus) dan Panitia Kerja (Panja) yang dibentuk diantaranya untuk menjawab berbagai aspirasi/pengaduan dari masyarkaat yang masuk ke DPRD, baik melalui Sekretariat Dewan ataupun ke AKD. Dalam rangka pelaksanaan fungsi pengawasan, DPRD juga memberikan pertimbangan dan persetujuan atas usul pengangkatan pejabat publik.

DPRD berfungsi sebagai lembaga pengawasan politik. DPRD sebagai struktur politik akan mewujudkan pola berlaku sebagai wahana melaksanakan demokrasi sesuai dengan tugasnya, salah satunya melakukan pengawasan terhadap penyelenggaraan pemerintahan daerah. Salah satu paradigma yang berkembang adalah akuntabilitas pemerintah daerah merupakan perwujudan kewajiban pemerintah untuk mempertanggung jawabkan keberhasilan dan kegagalannya.

\section{c. Pelaksanaan Fungsi Anggaran}

Pelaksanaan fungsi anggaran diwujudkan dengan membahas dan menyetujui rancangan anggaran pendapatan dan belanja daerah bersama kepala daerah. Alur pembahasan RAPBD diawali dengan pembahasan Kebijakan Umum Anggaran (KUA) dan Prioritas Plafon Anggaran Sementara (PPAS), setelah itu Rancangan APBD beserta dokumen pendukungnya dibahas.
Sejak periode keanggotaan DPRD Sulawesi Tenggara 2014-2019, seluruh pembahasan APBD dalam 1 (satu) siklus anggaran dapat diselesaikan DPRD bersama Pemerintah, yakni: 1) Perda Nomor 4 Tahun 2014 Pembahasan Pertanggungjawaban Pelaksanaan Anggaran Pendapatan dan Belanja Daerah Provinsi Sulawesi Tenggara Tahun Anggaran 2013; 2) Perda nomor 5 Tahun 2014 tentang Perubahan Anggaran Pendapatan dan Belanja Daerah Provinsi Sulawesi Tenggara Tahun Anggaran 2014; 3) Perda Nomor 14 tahun 2014 tentang APBD Prov. Sultra T.A. 2015; 4) Perda Nomor 4 Tahun 2015 tentang Pertanggungjawaban Pelaksanaan Anggaran Pendapatan dan Belanja Daerah Provinsi Sulawesi Tenggara Tahun Anggaran 2014; 5) Perda Nomor 5 Tahun 2015 tentang Perubahan Anggaran Pendapatan dan Belanja Daerah Provinsi Sulawesi Tenggara Tahun Anggaran 2015; 6) Perda Nomor 9 Tahun 2015 tentang Anggaran Pendapatan dan Belanja Daerah Provinsi Sulawesi Tenggara Tahun Anggaran 2016; 7). Perda Nomor 6 Tahun 2016 tentang Pertanggungjawaban Pelaksanaan Anggaran Pendapatan dan Belanja Daerah Provinsi Sulawesi Tenggara Tahun Anggaran 2015; 8). Perda Nomor 8 Tahun 2016 tentang Perubahan Anggaran Pendapatan dan Belanja Daerah Provinsi Sulawesi Tenggara Tahun Anggaran 2016; 9). Perda Nomor 16 Tahun 2016 tentang Anggaran Pendapatan dan Belanja Daerah Provinsi Sulawesi Tenggara Tahun Anggaran 2017; 10). Perda Nomor 5 Tahun 2017 tentang Pertanggungjawaban Pelaksanaan Anggaran Pendapatan dan Belanja Daerah Provinsi Sulawesi Tenggara Tahun Anggaran 2016; 11). Perda Nomor 9 Tahun 2017 tentang Perubahan Anggaran Pendapatan dan Belanja Daerah Provinsi Sulawesi Tenggara Tahun Anggaran 2017; 12). Perda Nomor 10 Tahun 2017 tentang Anggaran Pendapatan dan Belanja Daerah Provinsi Sulawesi Tenggara Tahun Anggaran 2018; 12). Perda tentang Pertanggungjawaban Pelaksanaan APBD T.A. 2017; 13). Perda tentang Perubahan APBD T.A. 2018; 14). Raperda tentang Anggaran Pendapatan Dan Belanja Daerah TA 2019. Di samping itu, dalam proses 
pembahasan APBD, DPRD melalui Badan Anggaran juga melakukan kegiatan Rapat Dengar Pendapat (RDP), audiensi, dan kunjungan kerja.

Strategi Meningkatkan Kepercayaan Publik

a. Peningkatan transparansi dan akuntabilitas DPRD

Berdasarkan temuan penelitian menujukkan aspek transparansi dan tanggung jawab DPRD mendapatkan penilaian yang masih rendah oleh publik. Oleh karena itu peningkatan akuntabilitas dan transparansi merupakan salah satu strategi dalam meningkatkan kepercayaan publik terhadap DPRD. Transparansi dan akuntabilitas adalah syarat utama terbentuknya pemerintahan yang demokratis. Hanya dengan transparansi dan akuntabilitas, DPRD dapat menjamin bahwa penyelenggaraan negara dan pemerintahan yang responsive dan bertanggung jawab terhadap kebutuhan \& harapan-harapan masyarakat.

Dalam rangka meningkatkan akuntabilitas dan transparansi, maka keterbukaan informasi publik merupakan prinsip yang harus dimiliki dan diterapkan oleh DPRD.

Keterbukaan informasi publik di DPRD dapat pula diwujudkan dalam bentuk transparansi rapat-rapat dewan yaitu membuka kesempatan bagi masyarakat untuk mengikuti sidang-sidang yang ada di DPRD. Semakin luas kesempatan bagi masyarakat untuk hadir dalam persidangan maka tingkat transparansi persidangan juga semakin tinggi. Untuk mengatasi hal tersebut, dan sebagai bentuk perwujudan transparansi dan akuntabilitas DPRD maka perlunya ketentuan Tata Tertib yang mengatur tentang pelaksanaan rapat-rapat dewan.

\section{b. Peningkatan Masyarakat Tentang DPRD}

Berdasarkan temuan penelitian menujukkan aspek peran dan kinerja DPRD mendapatkan penilaian yang efektif. Oleh karena itu, peningkatan kepercayaan publik terhadap DPRD sangat penting untuk di lakukan. Langkah penting yang akan dilakukan adalah memberikan pemahaman yang benar tentang DPRD terhadap masyarakat. Masyarakat harus paham tentang DPRD, baik tugas dan fungsinya maupun produk-produk yang dihasilkannya. Penyampaian produk-produk DPRD kepada publik merupakan bagian dari pembelajaran. Untuk itu, DPRD harus mengembangkan instrumen yang dapat mengomunikasikan hasil kerja DPRD tersebut kepada publik sekaligus mampu mendorong partisipasi publik dalam proses pelaksanaan fungsi, tugas, dan kewenangan DPRD. Untuk mencapai efektivitas dan efisien tata kelola persidangan dan penyampaian hasil kerja DPRD, diperlukan pengembangan dan pengelolaan teknologi informasi (TI) yang andal.

\section{c. Meningkatkan \\ Dukungan \\ Administrasi Dan Teknis Terhadap Pelaksanaan Fungsi Dan Tugas DPRD}

Berdasarkan temuan penelitian menujukkan bahwa dukungan administrasi dan dukungan teknis dalam pelaksanaan tugas dan fungsi DPRD, yang dalam hal ini diperankan oleh sekertariat dewan masih lamban, konservatif dan minim inovasi. Oleh karena itu, proses reformasi birokrasi Setwan DPRD perlu dilakukan guna memperkuat kelembagaan DPRD. Salah satu agenda reformasi birokasi yaitu dengan mengembangkan konsep manajemen parlemen. Secara umum tujuan yang ingin dicapai melalui pelaksanaan reformasi birokrasi dan pengembangan manajemen keparlemenan oleh Setwan DPRD adalah menghasilkan organisasi profesional, yaitu organisasi yang memiliki produktivitas yang tinggi dan berkualitas, serta bertanggung jawab dalam pelaksanaan tugas pokok dan fungsi yang diemban dan disertai integritas yang tinggi dari SDM pelaksananya. Dalam jangka panjang reformasi Setwan DPRD dan pengembangan manajemen keparlemenan adalah mengurangi kesenjangan antara harapan DPRD dan kinerja Setwan DPRD. Apabila Setwan DPRD tidak melakukan berbagai perubahan, kesenjangan itu akan semakin besar. Di masa mendatang semua keperluan dukungan DPRD diharapkan dapat dilaksanakan oleh organisasi Setwan DPRD sehingga kepuasan DPRD terhadap 
kinerja Setwan DPRD akan lebih meningkat.

\section{d. Peningakatan Dukungan Tenaga \\ Ahli/Staf Ahli}

Berdasarkan temuan penelitian menujukkan tenaga ahli yang dimiliki oleh DPRD masih minim baik dari jumlah maupun kapasitas keahlian yang dimiliki. Tenaga ahli DPRD saat ini masih didominasi oleh lulusan sarjana dan pola rekruitmen mengadandalkan jejaring dibanding profesionalitas. Padahal dalam rnelaksanakan fungsi legislasi, DPRD perlu dibantu oleh staf yang memiliki kualifikasi tertentu dan kecakapan teknis di bidang peraturan perundangundangan. Begitu juga dalam melaksanakan fungsi anggaran. DPRD perlu dibantu oleh staf yang memiliki kualifikasi dan kecakapan di bidang anggaran. Sama halnya untuk rnendukung pelaksanaan fungsi legislasi dan anggaran, untuk mendukung fungsi pengawasan, DPRD harus dibantu oleh staf yang memiliki kualifikasi dan kecakapan teknis di bidang analisis akuntabilitas keuangan dan analisis kebijakan. Selain itu, keberadaan staf peneliti yang berfungsi dan bertugas melakukan kajian dan penelitian terhadap isu-isu yang terkait dengan ketiga fungsi DPRD.

\section{e. Optimalisasi Peran Humas DPRD}

Temuan penelitian menujukkan bahwa peran Humas dalam membangun citra positif DPRD masih minim inovasi. Keberadaan Humas hanya diimplementasikan dalam bentuk pendokumentasian dan pelaksanaan suatu kegiatan, sementara peran membangun opini publik dan sosialisasi tugas-tugas dewan belum terlaksana dengan optimal. Pada organisasi modern peran kehumasan harus menjadi sistem pendukung terdepan dalam mengomunikasikan kegiatan dan produk DPRD dalam pelaksanaan fungsi legislasi, anggaran, dan pengawasan kepada masyarakat serta sekaligus berperan dalam mengelola arus informasi dari luar ke dalam DPRD. Sebagai pelaksana dari mandat rakyat, DPRD wajib menyampaikan kinerjanya kepada masyarakat. Upaya yang perlu diprioritaskan pada penguatan kehumasan DPRD dalam rangka pencitraan diantaranya: 1). Pengoptimalan peran tim kehumasan dalam membangun opini publik, menganalisis isi media, dan menyusun pengelolaan media (media treatment); 2). Pengoptimalan peran pimpinan AKD untuk mengomunikasikan hasil kegiatan AKD yang perlu disampaikan kepada publik; 3). Pengoptimalan dukungan kehumasan kepada Pimpinan DPRD sebagai juru bicara DPRD; 4). Peningkatan kerja sama dengan media massa dalam rangka menyosialisasikan kinerja dan meningkatkan citra DPRD di masyarakat; 5). Peliputan media massa di DPRD, serta Pedoman Pengelolaan Kehumasan DPRD yang didukung oleh ketersediaan anggaran, sarana, dan prasarana kehumasan yang memadai; dan 6). Penyiapan digitalisasi TV Parlemen.

\section{f. Perwujudan Teknologi Informasi dan Komunikasi Yang Terintegrasi}

Temuan penelitian menujukkan bahwa ketersediaan data dan informasi tentang DPRD belum terdigitalisasi dan terintegrasi. DPRD sebagai perwakilan rakyat dituntut untuk responsif terhadap berbagai perubahan yang terjadi di masyarakat. Salah satu hal penting yang secara global disadari adalah pemanfaatan teknologi untuk membangun komunikasi interpersonal yang lebih baik dan demokratis dengan masyarakat. Setwan DPRD tidak hanya memberikan layanan yang bersifat teknis administratif serta sarana dan prasarana, tetapi juga menjalankan tugas penyediaan data dan infomasi yang menjadi bahan bagi AKD dan anggota DPRD dalam menjalankan tugas dan fungsinya, serta menyediakan data dan informasi untuk publik. Untuk itu, arah kebijakan dalam upaya peningkatan kepercayaan publik terhadap DPRD adalah pengembangan sistem tata kelola, moderinisasi dokumentasi dan risalah, serta pengembangan basis data (data base) yang terintegrasi di antara unit-unit kerja. Arah kebijakan tersebut juga perlu didukung dengan arah kebijakan peningkatan sistem TI yang mendukung kerja-kerja DPRD dan unsur penunjang 
serta sejalan dengan implementasi konsep kawasan terintegrasi dan pengembangan e- Parliament.

g. Pengelolaan website, penggunaan media sosial dan penyediaan TV dan Radio Parlemen serta majalah parlemen

Temuan penelitian menujukkan bahwa keberadaan website, media sosial dan media penyiaran informasi DPRD belum dimiliki oleh DPRD. Dalam konsep parlemen modern dan terbukan peran media sosial dan website melaksanakan fungsi kehumasan parlemen dimedia sosial, dapat memudahkan aksesibilitas publik terhadap DPRD, melakukan rekam jejak peraturan daerah melalui website, menyajikan database aktivitas media sosial, serta melakukan monitoring media sosial dan website. Oleh karena itu DPRD perlu menyediakan dan mengelola akun media sosial yang dapat seperti: TWITTER, FACEBOOK, INSTAGRAM, YOUTUBE. Disamping media sosial, keberadaan saluran media konvensional TV, Radio dan majalah dapat dapat disediakan untuk membangun citra positif DPRD.

\section{PENUTUP}

\section{Kesimpulan}

1. Tingkat kepercayaan publik terhadap DPRD berada ada dalam kategori sedang dengan skor tingkat kepercayaan publik 3,23 skala Likert dengan rentang kriteria sebesar 64,47 $\%$. Aspek transparansi DPRD dinilai oleh publik masih rendah. Sementara aspek kepercayaan dan kejujuran, tanggung jawab, kompetensi, kinerja, kepedulian dan kedekatan serta komitmen berada dalam kategori sedang. Selanjutnya integritas dan etika berada dalam kategori tingkat kepercayaan yang tinggi.

2. Kinerja DPRD Provinsi Sulawesi Tenggara dalam pelaksanaan fungsi legislasi, pengawasan dan penganggaran belum berjalan seiring. Pelaksanaan fungsi legislasi dan penganggaran lebih dominan dibanding fungsi pengawasan. Fungsi legislasi DPRD Provinsi Sulawesi Tenggara terbilang produktif yaitu mampu menghasilkan 64 Perda dalam kurun waktu 4 tahun (20132018). Meksi demikian dari 64 Perda yang dihasilkan tersebut, DPRD hanya menginisasi $25 \%$, selebihnya $75 \%$ berasal dari inisiatif eksekutif.

3. Strategi mengembalikan kepercayaan publik terhadap DPRD dapat dilakukan dengan berbagai langkah, meliputi: a). Peningkatan akuntabilitas dan transparansi DPRD; b). Penguatan Kelembagaan DPRD; c). Peningkatan Pemahaman Masyarakat Tentang DPRD; d). Meningkatkan Dukungan Administrasi Dan Teknis Terhadap Pelaksanaan Fungsi Dan Tugas DPRD; e). Peningakatan Dukungan Tenaga Ahli/Staf Ahli; f). Optimalisasi Peran Humas DPRD; g). Perwujudan Teknologi Informasi dan Komunikasi Yang Terintegrasi; h). Pengelolaan website, penggunaan media sosial dan penyediaan TV dan Radio Parlemen serta majalah parlemen.

\section{Saran}

$1 . \quad$ Peningkata $\mathrm{n}$ kepercayaan publik terhadap DPRD Sulawesi Tenggara selain dapat ditempuh dengan memperbaiki kualitas individu anggota dewan juga memerlukan perbaikan kualitas kelembagaan dewan. Perbaikan kualitas individu anggota memerlukan berbagai instrumen mulai dari perbaikan partisipasi politik, proses pemilihan serta tingkat pendidikan. Sedangkan perbaikan kualitas kelembagaan DPRD dapat dilakukan dengan mengeluarkan kebijakan strategis, seperti manajemen parlemen, reformasi birokrasi kesekertariatan dewan, optimalisasi peran Humas, penggunaan media teknologi dalam 
penyerapan aspirasi dan sosialisasi kegiatan dewan.

2. an publik terhadap DPRD dapat ditingkatkan pula dengan perbaikan kinerja DPRD yaitu produktivitas legislasi, efektivitas pengawasan, serta transparansi dan kelancaraan pembahasan anggaran. Oleh karena itu peningkatan kepercayaan publik terhadap DPRD dapat ditempuh dengan perbaikan dan pengoptimalisasian fungsi-fungsi DPRD. Dalam proses legislasi DPRD harus memiliki target waktu dalam proses pembahasan, aspiratif dan memiliki manfaat ekonomi maupun sosial. Begitupun dalam proses penganggaran dan pengawasan harus berjalan transparan serta konsisten.

3. an publik terhadap DPRD akan semakin kokoh, jika dalam proses politik di DPRD melibatkan partisipasi publik yang luas, transparan dan akuntabel. Oleh karena itu DPRD sebagai fungsi representasi rakyat harus memegang prinsip partipasi, transparansi dan akuntablitas dalam setiap pengambilan keputusan politik

\section{REFERENCES}

\section{JOURNAL:}

Coleman, James. S. 1988. Social Capital in the Creation of Human Capital, The American Journal of Sociology.

Morgan, R.M dan Hunt, SD. 1994. The Comitmen trust theory of relationship marketing. Journal of Marketing. Vol. 58. No.3, pp 20-38.

Moorman, Christine dkk. 1993. Factor Affecting Trust in Market Reseach Relationship. Journal of Marketing. Vol. 57. Pp 81-101.

Putnam, R.D. 2000. Bowling Alone: The Collapse and Revival of American
Comunity. Simon and Schuter, New York.

\section{BOOK:}

Alfian dan Syamsudin, Nazaruddin (ed). 1991. Profil Budaya Politik Indonesia. Jakarta, Pustaka Utama Grafiti.

Bachmann, R. and Zaheer, A. 2006. Handbook of Trust Reseach. USA, Edward Edgar Publishing, Incorporated.

DPR RI. 2016. Membangun Demokrasi Yang Efektif Melalui Kerja Nyata Parlemen.

Fukuyama. F. 1995. Trust: the Social Virtues and the Creation of Prosperity. Hamish Hamilton, London.

Field, John. 2010. Modal Sosial. Kreasi Wacana, Yogyakarta.

Inter-Parliamentary Union. 2008. Evaluating Parliament - A selfassessment toolkit for parliaments. SRO-Kundig, Geneva, Switzerland

Kartono, Kartini. 1995. Psikologi Anak (Psikilogi Perkembangan). Bandung, CV Mandar MAJU.

Mariyah, Chusnul dan Reni Suwarso (ed). 2016. Parlemen Modern dan Terbuka. UI Press, Jakarta.

\section{Internet:}

Zona Sultra, "Tunjangan Transportasi Naik, Akankah Anggota DPRD Rajin?", 4 September 2017. https://zonasultra.com/tunjangantransportasi-naik-akankah-anggotadprd-rajin.html, diakses 21 september 2018.

Zona Sultra, "Setelah Tunjangan Dinaikkan, 13 Anggota DPRD Sultra malah absen paripurna", 11 September 2017. https://zonasultra.com/setelahtunjangan-dinaikkan-13-anggotadprd-sultra-malah-absenparipurna.html, diakses 21 september 2018. 

(Online) 